\title{
Conservation value of a natural protected area in the state of Puebla, Mexico
}

\author{
Valor de conservación de una área natural protegida en Puebla, México
}

\author{
Ernesto Iván Badano ${ }^{1 凶}$, Jerónimo García-Guzmán², Carlos Hernán Vergara-Briceño², Luis Enrique Martínez- \\ Romero $^{3}$, María de las Nieves Barranco-León ${ }^{2}$, Florencio Luna-Castellanos², Ana María Acuña-Cors², Miguel \\ Ángel García-Valenzuela ${ }^{2}$ y Carlos Renato Ramos-Palacios ${ }^{1}$ \\ ${ }^{1}$ División de Ciencias Ambientales, Instituto Potosino de Investigación Cientifica y Tecnológica, Camino a la Presa San José 2055, Colonia Lomas 4ta. \\ Sección, 78216 San Luis Potosí, San Luis Potosí, México. \\ ${ }^{2}$ Escuela de Ciencias, Universidad de las Américas Puebla, Santa Catarina Mártir, 72820 San Andrés Cholula, Puebla, México. \\ ${ }^{3}$ Parque Estatal Flor del Bosque, Secretaria de Sustentabilidad Ambiental y Ordenamiento Territorial Gobierno del Estado de Puebla, Carril a San \\ Bartolo S/N, Exhacienda San Bartolo Flor del Bosque, Colonia Casa Blanca, 72360 Amozoc de Mota, Puebla, México. \\ 凶ernesto.badano@ipicyt.edu.mx
}

\begin{abstract}
Mexico has several natural protected areas (NPAs) managed by state administrations. However, the aims these NPAs are more closely related to local political contexts than to their importance as reservoirs of biodiversity. In this study, we assessed the conservation value of the park Flor del Bosque, in the state of Puebla. Since this park contains both, well-preserved and human-disturbed habitats, we compared the diversity of plants and birds between these habitat types. Later, to assess its conservation value, the total diversity of the park was compared with that from an external, unprotected site with similar vegetation structure. In the park, the diversity of both groups of organisms was higher at well-preserved rather than at disturbed habitats. Furthermore, the analyses indicated that the entire diversity of the park is substantially higher than that of the external site. Thus, we suggest that these type of studies should be promoted by the state governments to determine the conservation value of their NPAs and, therefore aid in the development of adequate management programs for these sites.
\end{abstract}

Key words: birds, biological conservation, diversity analyses, state parks, woody plants.

Resumen. México tiene varias áreas naturales protegidas (ANPs) que dependen de los gobiernos estatales. Sin embargo, los objetivos de estas ANPs están más estrechamente vinculados a los contextos políticos locales que a su importancia como reservorios de la biodiversidad. En este estudio evaluamos el valor de conservación del parque ecológico Flor del Bosque, en el estado de Puebla. Debido a que el parque tiene hábitats bien conservados y antropogénicamente perturbados, comparamos la diversidad de plantas y aves entre esos tipos de hábitats. Después, para evaluar el valor de conservación, la diversidad total del parque fue comparada con la de un sitio externo, no protegido, con estructura similar en cuanto al tipo de vegetación. En el parque, la diversidad de plantas y aves fue más alta en los hábitats bien conservados que en los perturbados. Además, los análisis mostraron que la diversidad total del parque es muy superior a la del sitio externo. Por lo tanto, sugerimos que este tipo de trabajos deben ser promovidos por los gobiernos estatales para determinar el valor de conservación de sus ANPs y así, desarrollar programas de manejo adecuados para esos sitios.

Palabras clave: aves, conservación biológica, análisis de diversidad, parques estatales, plantas leñosas.

\section{Introduction}

Environmental conservation is crucial for Mexico because the country contains almost $10 \%$ of the world's biodiversity (Espinosa-Organista et al., 2008). The federal government currently administrates a total of 174 Natural Protected Areas (NPAs), which cover more than 25.3 million hectares. The first federal NPA was the National Park El Chico, in the state of Hidalgo,

Recibido: 24 mayo 2011; aceptado: 29 febrero 2012 created in 1899 (Vargas-Márquez et al., 2000). More recently, the state governments have become interested in participating in these actions and the state of Chiapas established the first state NPA, the Typical Natural Area Bosque de Coníferas de Chanal, in 1972 (VargasMárquez et al., 2001). Since then, Mexican states have given rise to 173 state NPAs. However, the reasons for which state NPAs are created range from preserving part of a regional ecosystem characterized by its scenic or cultural value, to the establishment of recreation sites associated local economic activities (Vargas-Márquez et al., 2001). Therefore, the aims of the state NPAs seem to 
be more closely linked to local socio-political contexts than to their importance as reservoirs of the Mexican biodiversity.

The current situation in most state NPAs is the lack of knowledge about the amount of natural diversity they preserve. In this study, we focused in determining the conservation value of the state ecological-recreation park known as Flor del Bosque. This park was created in 1982 to preserve a small relict of oak forest within the city of Puebla. However, within the park, there are several areas in which the forest was cleared during the first half of the $20^{\text {th }}$ century and replaced by anthropogenic habitats (Badano et al., 2009, 2011). With this picture in mind, this study was aimed to determine the conservation value of the park and 2 hypotheses were proposed: 1) since the oak forest comprises the original vegetation of the site, this habitat should show higher diversity of plants and animals than the man-made disturbed habitats of the park, and 2) if the park is effectively acting as reservoir for the flora and fauna, the diversity of native species should be higher, or at least similar, than that observed in an unprotected area with comparable vegetation structure.

\section{Materials and methods}

Study sites. The state park Flor del Bosque is located in the municipality of Amozoc de Mota, $10 \mathrm{~km}$ to southeast of downtown of city of Puebla $\left(19^{\circ} 01^{\prime} \mathrm{N}, 98^{\circ} 20^{\prime} \mathrm{W}\right)$. Geologically, the park belongs to the Amozoc mountain range, mainly composed of limestone rocks. It covers 699.2 ha and its elevation ranges between 2100 and 2 $470 \mathrm{~m}$. Climate across the region is temperate-subhumid with rainfall in the summer months (García, 1988). The mean annual temperature in the park is $16.33^{\circ} \mathrm{C}$ $\left( \pm 3.21^{\circ} \mathrm{C}\right)$. May is the hottest month of the year, with maximum temperatures up to $34^{\circ} \mathrm{C}$, and January is the coldest month, with minimum temperatures below $0^{\circ} \mathrm{C}$. The main precipitation events occur between June and October, and total annual rainfall ranges between 750 and $950 \mathrm{~mm}$. There are 3 vegetation types within the park: oak forest moderately impacted by human activities; secondary grasslands that developed after the forest was cleared more than 70 years ago; and abandoned plantations of Eucalyptus spp., introduced in deforested sites 40-50 years ago for forestry practices (Badano et al., 2011).

The external study site was Sierra del Tentzo, a small mountain range located $28.6 \mathrm{~km}$ to the south of the park. It limits on the municipalities of Tzicatlacoyan to the north (18 $\left.50^{\prime} 23^{\prime \prime} \mathrm{N}, 98^{\circ} 02^{\prime} 44^{\prime \prime} \mathrm{W}\right)$ and Huatlatlauca to the south $\left(18^{\circ} 40^{\prime} 46^{\prime \prime} \mathrm{N}, 98^{\circ} 30^{\prime} 01^{\prime \prime} \mathrm{W}\right)$, while the municipality of Molcaxac is located to the east (18 $44^{\prime} 18^{\prime \prime}$
$\left.\mathrm{N}, 97^{\circ} 54^{\prime} 40^{\prime \prime} \mathrm{W}\right)$. This mountain range reaches elevations between 2000 and $2350 \mathrm{~m}$ and is composed of limestone rocks. Climate is temperate, annual average temperature is $21^{\circ} \mathrm{C}$ and $16^{\circ} \mathrm{C}$ in summer and winter, respectively. Precipitation averages $800 \mathrm{~mm}$ per year and 95\% of rainfall events occurring between May and September. Slopes of the hills are covered by oak forests, but there are small patches of secondary vegetation that developed after forest clearing. There are small agricultural fields in the lowlands, most of them dedicated to temporary crops (INEGI, 1987).

The 2 study sites are geographically located within the sub-province of Lakes and Volcanoes of Anahuac (Gutiérrez-Herrera et al., 2003). Further, phytogeographically they belong to the province of the Trans-Mexican Volcanic Belt, which is located within the boarder Mesoamerican Mountain Region of oak forests (Rzedowski, 2006).

Woody plants. The woody flora of both sites was sampled between October 2009 and July 2010. To systematically sample plant species at the different habitat types of the park Flor del Bosque, a square grid of 500 x 500 m was superimposed on an aerial image of the park by using UTM coordinates (Fig. 1). This procedure resulted in 24 quadrants of 25 ha each. We later selected 7 quadrants in which most of their area were covered by forest (quadrats 1, 3, 6, 7, 8, 9 and 10 in Fig. 1). We also selected 4 quadrats containing Eucalyptus plantations (quadrats 2, 4, 5 and 15 in Fig. 1) and another 4 quadrats covered by grasslands (quadrats 16, 17, 18 and 23 in Fig. 1). Within each quadrant, five $50 \mathrm{~m}$-long parallel linear transects and spaced $50 \mathrm{~m}$ between each other were laid out. All transects were located within the predominant vegetation type of each quadrant, maintaining a minimum distance of $25 \mathrm{~m}$ from any other vegetation type. After that, we identified and counted the individuals of all woody species on a $4 \mathrm{~m}$-wide strip along each transect (i.e., each transect has $50 \mathrm{~m} \mathrm{x} 4 \mathrm{~m}$ and, therefore, the sampling area was $200 \mathrm{~m}^{2}$ per transect). This resulted in 35 transects for the oak forest, 20 for the Eucalyptus plantation and 15 for the grasslands. We then estimated the density of each species at each habitat type by extrapolating the number of individuals detected in the sampling transects to a surface area of 1.0 ha.

Since there are no plantations or extensive secondary grasslands in Sierra del Tentzo, we focused on sampling vegetation in the oak forest. For this, we randomly selected 5 sampling sites on the slopes of this mountain range, avoiding sites near crops and human settlements. The geographic coordinates of these sites were: $18^{\circ} 46^{\prime} 22^{\prime \prime} \mathrm{N}$, 975' $20^{\prime \prime} \mathrm{W} ; 18^{\circ} 46^{\prime} 38^{\prime \prime} \mathrm{N}, 97^{\circ} 58^{\prime} 34^{\prime \prime} \mathrm{W} ; 18^{\circ} 44^{\prime} 22^{\prime \prime} \mathrm{N}$,

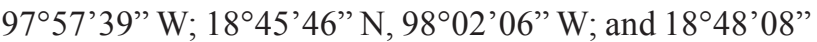




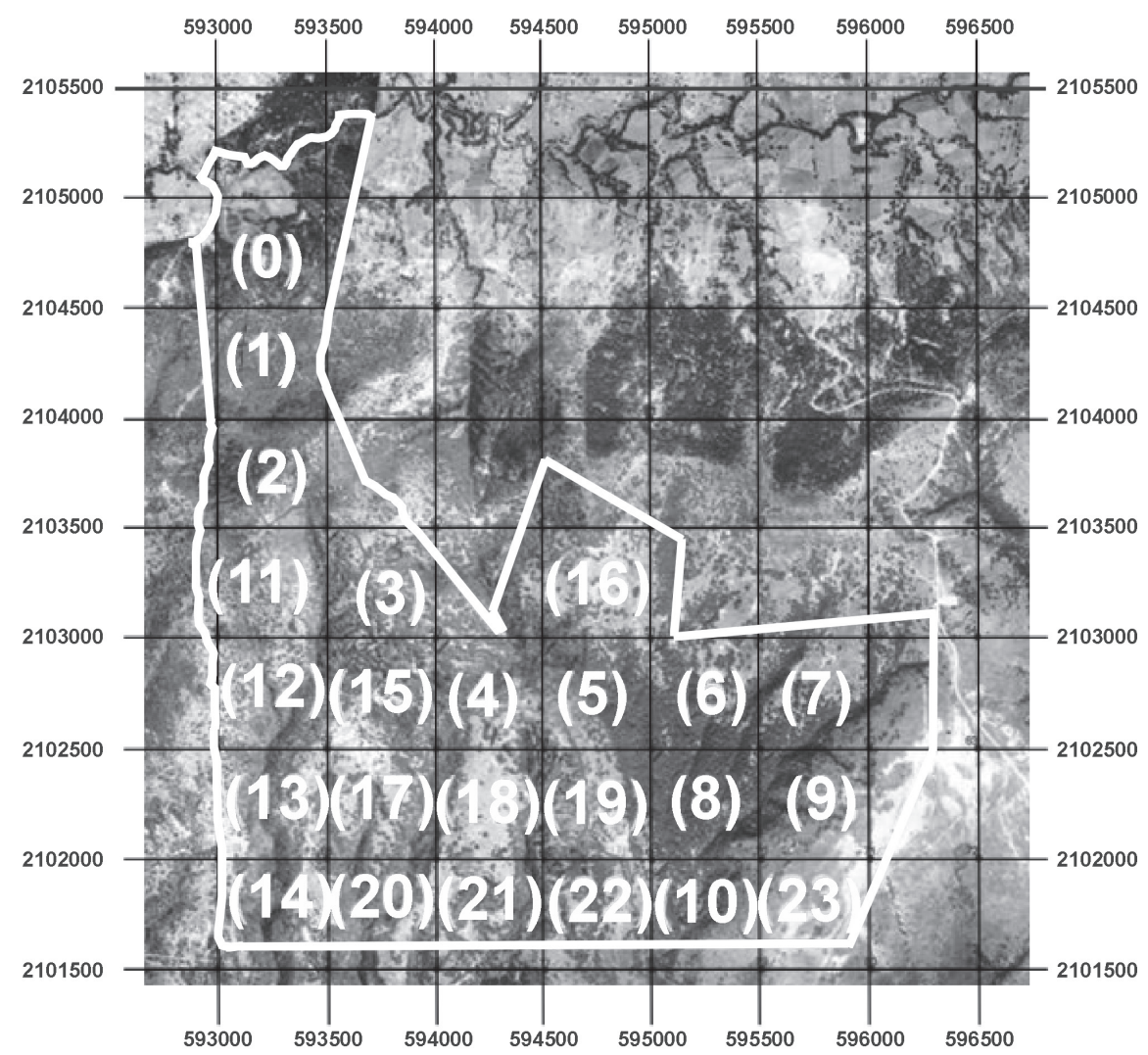

Figure 1. Square grid of 500 x $500 \mathrm{~m}$ superimposed to an aerial image of the state park Flor del Bosque for performing the sampling of woody plants at its different habitat types (oak forest; eucalyptus plantations and grasslands). Numbers on the sides of the image are UTM coordinates. Numbers in brackets within the image indicate the quadrat numbers used to determine the sampling sites at each habitat type.

N, 98 $01^{\prime} 59^{\prime \prime}$ W. At each site we delimited a 500 x 500 $\mathrm{m}$ quadrant and vegetation was sampled by following the same procedure described above. This resulted in 35 transects of $50 \mathrm{~m} \mathrm{x} 4 \mathrm{~m}$ for the oak forest in the external site, and this data was also used to estimate the density of the different species at this site.

In the field, we recorded the growth-form of each woody plant (tree or shrub). Vouchers of the different species were collected, carried to the laboratory and dried in a ventilated stove. For the taxonomic identification we consulted the following herbariums: HUAP (Puebla), MEXU (México City), XAL (Xalapa) and SLPM (San Luis Potosí). All specimens were deposited at the Herbarium of Universidad de las Américas-Puebla (Puebla, México). Once specimens were identified, we determined whether they belonged to native species (i.e., species whose original biogeographic distribution includes the geopolitical limits of México) or exotic species (i.e., that arrived to Mexico from other biogeographic region due to human activities). Additionally, we indicated which native species are endemic to México. This classification was performed by following the Taxonomic Catalog of Species of Mexico (Ocegueda and Llorente-Bousquets, 2008). Furthermore, we also determined whether native species are included in some protection category in the Mexican Normativity of Environmental Protection (DOF, 2010).

To determine whether diversity of woody plants varies among the different habitats of the park, we focused in 2 basic community attributes: species richness $(S)$ and Shannon-Wiener's index of proportional diversity $\left(H^{\prime}\right)$. To avoid biases due to differences in sampling efforts, both community attributes were estimated through sample-based rarefactions (Gotelli and Colwell, 2001). These estimations were conducted with the software EstimateS v 8.2 (Colwell, 2009), and transects from the different habitat types were considered as samples. However, statistical comparisons of rarefied values of $S$ and $H^{\prime}$ can only be conducted at the same sampling size (n) (Gotelli and Colwell, 2001); thus, since our sampling effort varied among habitat types, all estimations of $S$ and $H$ ' were performed at $n=20$, that was the total number 
of samples (transects) taken at Eucalyptus plantations and grasslands. Both $S$ and $H^{\prime}$ were then computed 1000 times at $n=20$. On each rarefaction run, $S$ was calculated as the number of species included in the re-sample, while $H$ ' was computed as:

$$
\sum_{i=1}^{S} p i \times \ln (p i)
$$

where $p i$ is the proportion of individuals of the $i^{\text {th }}$ species in the sample and $\ln (p i)$ is its natural logarithm; Krebs, 1999. The 1000 values of $S$ and $H^{\prime}$ were later averaged to obtain the mean value of each of these community attributes at $n=20$. Moreover, to determine whether these values significantly differed among the different habitat types of the park, we computed the $95 \%$ confidence interval for the mean values of $S$ and $H^{\prime}$ estimated at each sampling size. Thus, significant differences were assumed if confidence intervals of $S$ and $H$ ' did not overlap between habitat types.

To compare plant diversity between Flor del Bosque and Sierra del Tentzo, 2 additional estimations of $S$ and $H^{\prime}$ were performed by using the rarefaction protocol described above. In a first instance, the values of $S$ and $H^{\prime}$ were computed at $n=20$ for the oak forest we sampled at Sierra del Tentzo. Later, samples from the different habitat types of the park were pooled and $S$ and $H^{\prime}$ were also estimated at $n=20$; these values are then indicative of the whole plant diversity of the park. All these comparisons were firstly performed by including both shrubs and trees. The same comparisons were later performed separately for trees and shrubs to determine the contribution of each group to the plant diversity of the different sites.

Birds. To determine the diversity of birds, we established 4 fixed counting-points within the oak forest of the park (quadrats 1, 2, 6 and 8 in Fig. 1). Other 4 counting-points were located at Eucalyptus plantations (quadrats 2, 4, 5 and 15 in Fig. 1). Grasslands were omitted from this sampling since there are no trees that birds may use for perching or nesting. Sampling points were located within the focal vegetation type at each quadrat (oak forest or Eucalyptus plantations). Two well-trained bird observers were placed at each point and they identified and counted all bird species within their visual rank with binoculars Pentax XCF series $12 \times 50$. This sampling was performed for 2 consecutive days at each point, and it was repeated at 2 intervals during the day from 7:00 to 8:00 hrs and from 18:00 to 19:00 hrs. This was because these are the day periods where birds are more active. At the external study site, Sierra del Tentzo, birds were sampled with the same methodology at 4 of the previously delimited quadrats used for sampling vegetation.

Since the different sites considered in this study may be used by both, permanent-resident and migratory birds, they were sampled during 2 seasons. We first sampled birds at the warm and wet season (late July 2010), where only permanent-resident birds are present. Later, birds were sampled during the cold and dry season (late January 2011), which coincides with the North-South migration of several species. In both sampling seasons, birds were identified with the field guides of Howell and Webb (1995) and Chalif and Peterson (1999). We also determined if detected birds are native or exotic by using the Taxonomic Catalog of Species of Mexico (Ocegueda and LlorenteBousquets, 2008), and whether they are included in some protection category in the Mexican Normativity of Environmental Protection (DOF, 2010).

Rarefaction techniques were also used to compare bird diversity among habitat types of the park, as well as to assess differences in diversity between the park and the external site. However, since birds were sampled with a different methodology than plants, we used individualbased rarefactions instead of sample-based rarefactions. The main difference between these rarefaction protocols is that the first one computes community attributes (i.e., $S$ and $H^{\prime}$ ) for a given number of individuals, while the second one uses samples (Gotelli and Colwell, 2001). In other words, although both methods compute alpha-diversity measures, they use different sampling units. Individual-based rarefactions were performed with the software EcoSim v 7.7 (Gotelli and Entsminger, 2011). As mentioned above, statistical comparisons of rarefied values of $S$ and $H^{\prime}$ can be only performed at the same sampling size, $n$, that in this case is defined by a given number of individuals (Gotelli and Colwell, 2001). Therefore, all values of $S$ and $H^{\prime}$ were estimated at 52 individuals, which was the number for individuals recorded at the site with the lowest number of records (the Eucalyptus plantation of the park in the winter sampling). Bearing in mind these caveats, the diversity of bird assemblages was compared among sites by following the same procedure described for plants. Nevertheless, these comparisons were performed separately for the 2 sampling periods of birds (summer and winter) in order to obtain results as detailed as possible.

\section{Results}

Diversity of woody plants. At Flor del Bosque, we recorded 45 woody and succulent plant species belonging to 18 families (Table 1). Apart from Eucalyptus camaldulensis, no other exotic species was recorded. Among the native species, $31.1 \%$ of these were endemic to Mexico (Table 1). Only one tree species, Cupressus lusitanica, is subjected to special protection within the Mexican Normativity of Environmental Protection (DOF, 2010). Considering the total area of the park, the estimated density of native trees 
Table 1. Woody plant species lists from the different habitat types at the state park Flor del Bosque and from the external site, Sierra del Tentzo. The table indicates the family, name and authority (abbreviations following the TROPICOS database of the Missouri Botanical Garden; http://www.tropicos.org, consulted on May 14 $\left.{ }^{\text {th }} 2011\right)$, biogeographic origin ( $\mathrm{N}=$ native; En= Endemic; Ex = exotic), and life form $(\mathrm{T}=$ tree; $\mathrm{WS}=$ woody shrub; $\mathrm{SS}=$ succulent shrub) of each species the different sites considered in this study. Numbers in the body of the table indicate the estimated density (individuals/ha) of each species at the different habitat types of the park and at Sierra del Tentzo; $\mathrm{ND}=$ not detected

\begin{tabular}{|c|c|c|c|c|c|c|c|}
\hline Family & Species & $\begin{array}{l}\text { Biogeographic } \\
\text { origin }\end{array}$ & $\begin{array}{l}\text { Life } \\
\text { form }\end{array}$ & $\begin{array}{c}\text { State park } \\
\text { Flor del } \\
\text { Bosque } \\
\text { Oak forest }\end{array}$ & $\begin{array}{l}\text { Eucalyptus } \\
\text { plantations }\end{array}$ & Grasslands & $\begin{array}{c}\text { Sierra } \\
\text { del } \\
\text { Tentzo }\end{array}$ \\
\hline \multirow[t]{3}{*}{ Asparagaceae } & Agave potatorum Zucc. & En & SS & 72 & 118 & 7 & 38 \\
\hline & Agave salmiana Otto ex Salm-Dyck & $\mathrm{N}$ & SS & 36 & 12 & 13 & ND \\
\hline & Yucca periculosa Baker & $\mathrm{N}$ & SS & ND & ND & ND & 14 \\
\hline Anacardiaceae & $\begin{array}{l}\text { Actinocheita potentillifolia (Turcz.) } \\
\text { Bullock }\end{array}$ & $\mathrm{N}$ & $\mathrm{T}$ & ND & ND & ND & 16 \\
\hline Arecaceae & Brahea dulcis (Kunth) Mart. & $\mathrm{N}$ & $\mathrm{P}$ & ND & ND & ND & 438 \\
\hline \multirow[t]{5}{*}{ Asteraceae } & $\begin{array}{l}\text { Critoniopsis uniflora (Sch. Bip.) H. } \\
\text { Rob. }\end{array}$ & En & WS & 2 & 2 & ND & 4 \\
\hline & Gochnatia hypoleuca (DC.) A. Gray & $\mathrm{N}$ & WS & ND & ND & ND & 18 \\
\hline & Montanoa tomentosa Cerv. & $\mathrm{N}$ & WS & 66 & 227 & ND & 2 \\
\hline & $\begin{array}{l}\text { Pittocaulon praecox (Cav.) Rob. and } \\
\text { Brettell }\end{array}$ & En & $\mathrm{T}$ & 4 & ND & ND & ND \\
\hline & Senecio salignus DC. & $\mathrm{N}$ & WS & 157 & 167 & 10 & 4 \\
\hline Bignoneaceae & Tecoma stans (L.) Juss. ex Kunth & $\mathrm{N}$ & $\mathrm{T}$ & 5 & 10 & ND & 68 \\
\hline \multirow[t]{3}{*}{ Burseraceae } & Bursera fagaroides (Kunth) Engl. & $\mathrm{N}$ & $\mathrm{T}$ & ND & ND & ND & 4 \\
\hline & Bursera simaruba (L.) Sarg. & $\mathrm{N}$ & $\mathrm{T}$ & ND & ND & ND & 2 \\
\hline & Bursera biflora (Rose) Standl. & $\mathrm{N}$ & WS & ND & ND & ND & 4 \\
\hline \multirow[t]{2}{*}{ Cactaceae } & Opuntia pilifera F.A.C. Weber & $\mathrm{N}$ & SS & 4 & 2 & 7 & ND \\
\hline & Opuntia tomentosa Salm-Dyck & $\mathrm{N}$ & SS & 43 & 50 & 7 & 38 \\
\hline \multirow[t]{2}{*}{ Convolvulaceae } & $\begin{array}{l}\text { Ipomoea arborescens (Humb. and } \\
\text { Bonpl. ex Willd.) G. Don }\end{array}$ & $\mathrm{N}$ & $\mathrm{T}$ & 5 & 5 & ND & ND \\
\hline & $\begin{array}{l}\text { Ipomoea murucoides Roem. et } \\
\text { Schult. }\end{array}$ & $\mathrm{N}$ & $\mathrm{T}$ & 19 & 40 & ND & 22 \\
\hline \multirow[t]{4}{*}{ Cupressaceae } & Cupressus lusitanica Mill. & En & $\mathrm{T}$ & 7 & ND & ND & ND \\
\hline & Juniperus deppeana Steud. & En & $\mathrm{T}$ & 9 & 10 & ND & ND \\
\hline & $\begin{array}{l}\text { Juniperus flaccida var. flaccida } \\
\text { Schltdl. }\end{array}$ & $\mathrm{N}$ & $\mathrm{T}$ & 15 & 17 & ND & 148 \\
\hline & $\begin{array}{l}\text { Juniperus poblana (Martínez) R.P. } \\
\text { Adams }\end{array}$ & En & $\mathrm{T}$ & 16 & 12 & ND & ND \\
\hline \multirow[t]{2}{*}{ Ericaceae } & Arbutus xalapensis Kunth & $\mathrm{N}$ & $\mathrm{T}$ & 3 & 2 & ND & ND \\
\hline & Arctostaphylos pungens Kunth & $\mathrm{N}$ & WS & 38 & 10 & 3.33 & 16 \\
\hline \multirow[t]{2}{*}{ Euphorbiaceae } & $\begin{array}{l}\text { Cnidoscolus multilobus (Pax) I.M. } \\
\text { Johnst. }\end{array}$ & $\mathrm{N}$ & WS & ND & ND & ND & 2 \\
\hline & Croton adspersus Benth. & $\mathrm{N}$ & WS & 55 & 32 & ND & ND \\
\hline \multirow[t]{3}{*}{ Fabaceae } & Acacia angustissima (Mill.) Kuntze & $\mathrm{N}$ & WS & ND & ND & ND & 2 \\
\hline & Acacia constricta Benth. & $\mathrm{N}$ & WS & ND & ND & ND & 2 \\
\hline & Acacia mammifera Schltdl. & $\mathrm{N}$ & WS & ND & ND & ND & 18 \\
\hline
\end{tabular}


Table 1. Continues

\begin{tabular}{|c|c|c|c|c|c|c|c|}
\hline Family & Species & $\begin{array}{l}\text { Biogeographic } \\
\text { origin }\end{array}$ & $\begin{array}{l}\text { Life } \\
\text { form }\end{array}$ & $\begin{array}{c}\text { State park } \\
\text { Flor del } \\
\text { Bosque } \\
\text { Oak forest }\end{array}$ & $\begin{array}{l}\text { Eucalyptus } \\
\text { plantations }\end{array}$ & Grasslands & $\begin{array}{c}\text { Sierra } \\
\text { del } \\
\text { Tentzo }\end{array}$ \\
\hline & $\begin{array}{l}\text { Acacia pennatula (Schltdl. and } \\
\text { Cham.) Benth. }\end{array}$ & $\mathrm{N}$ & WS & ND & ND & ND & 6 \\
\hline & $\begin{array}{l}\text { Acacia schaffneri (S. Watson) F.J. } \\
\text { Herm. }\end{array}$ & $\mathrm{N}$ & WS & 3 & 5 & 7 & 2 \\
\hline & Bauhinia divaricata $\mathrm{L}$. & $\mathrm{N}$ & $\mathrm{T}$ & ND & ND & ND & 8 \\
\hline & $\begin{array}{l}\text { Calliandra grandiflora (L'Hér.) } \\
\text { Benth. }\end{array}$ & $\mathrm{N}$ & WS & 81 & 185 & 3 & ND \\
\hline & Dalea versicolor Zucc. & $\mathrm{N}$ & WS & 30 & 10 & ND & ND \\
\hline & $\begin{array}{l}\text { Desmodium molliculum (Kunth) } \\
\text { DC. }\end{array}$ & $\mathrm{N}$ & WS & ND & ND & ND & 18 \\
\hline & Erythrina flabelliformis Kearney & $\mathrm{N}$ & WS & ND & ND & ND & 8 \\
\hline & $\begin{array}{l}\text { Eysenhardtia polystachya (Ortega) } \\
\text { Sarg. }\end{array}$ & $\mathrm{N}$ & WS & 177 & 252 & ND & ND \\
\hline & $\begin{array}{l}\text { Leucaena esculenta (Moc. and Sessé } \\
\text { ex DC.) Benth. }\end{array}$ & $\mathrm{N}$ & $\mathrm{T}$ & ND & ND & ND & 38 \\
\hline & Mimosa acanthocarpa Poir. & $\mathrm{N}$ & WS & 6 & 12 & 7 & ND \\
\hline & Mimosa aculeaticarpa Ortega & $\mathrm{N}$ & WS & 196 & 290 & 10 & 168 \\
\hline & Mimosa biuncifera Benth. & $\mathrm{N}$ & WS & ND & ND & ND & 4 \\
\hline & Pithecellobium dulce (Roxb.) Benth. & $\mathrm{N}$ & WS & ND & ND & ND & 14 \\
\hline & $\begin{array}{l}\text { Senna multiglandulosa (Jacq.) H.S. } \\
\text { Irwin et Barneby }\end{array}$ & $\mathrm{N}$ & WS & 22 & 57 & ND & ND \\
\hline \multirow[t]{10}{*}{ Fagaceae } & Quercus candicans Née & En & $\mathrm{T}$ & 4 & ND & ND & ND \\
\hline & Quercus castanea Née & En & $\mathrm{T}$ & 179 & ND & 7 & 132 \\
\hline & Quercus crassipes Humb. et Bonpl. & En & $\mathrm{T}$ & 7 & ND & ND & ND \\
\hline & Quercus glabrescens Benth. & En & $\mathrm{T}$ & 53 & ND & ND & ND \\
\hline & $\begin{array}{l}\text { Quercus glaucoides M. Martens and } \\
\text { Galeotti }\end{array}$ & $\mathrm{N}$ & $\mathrm{T}$ & ND & ND & ND & 56 \\
\hline & Quercus laeta Liebm. & En & $\mathrm{T}$ & 156 & ND & ND & 216 \\
\hline & Quercus laurina Bonpl. & En & $\mathrm{T}$ & 44 & ND & 3 & 140 \\
\hline & Quercus mexicana Bonpl. & En & $\mathrm{T}$ & 2 & ND & ND & 4 \\
\hline & Quercus obtusata Bonpl. & En & $\mathrm{T}$ & 11 & ND & ND & ND \\
\hline & Quercus rugosa Née & En & $\mathrm{T}$ & 3 & ND & ND & 64 \\
\hline Lamiaceae & Salvia polystachya Cav. & $\mathrm{N}$ & WS & 432 & 277 & ND & ND \\
\hline Myrtaceae & Eucalyptus camaldulensis Dehnh. & Ex & $\mathrm{T}$ & 94 & 312 & ND & ND \\
\hline Pinaceae & $\begin{array}{l}\text { Pinus leiophylla Schiede ex Schltdl. } \\
\text { and Cham. }\end{array}$ & $\mathrm{N}$ & $\mathrm{T}$ & 2 & 2 & ND & ND \\
\hline \multirow[t]{3}{*}{ Rhamnacae } & Ceanothus coeruleus Lag. & $\mathrm{N}$ & WS & 1 & ND & ND & ND \\
\hline & $\begin{array}{l}\text { Karwinskia humboldtiana (Willd. ex } \\
\text { Roem. and Schult.) Zucc. }\end{array}$ & $\mathrm{N}$ & WS & ND & ND & ND & 42 \\
\hline & $\begin{array}{l}\text { Ziziphus amole (Sessé and Moc.) } \\
\text { M.C. Johnst. }\end{array}$ & $\mathrm{N}$ & WS & ND & ND & ND & 4 \\
\hline Rosaceae & Prunus serotina Ehrh. & $\mathrm{N}$ & $\mathrm{T}$ & 3 & ND & ND & ND \\
\hline
\end{tabular}


Table 1. Continues

\begin{tabular}{|c|c|c|c|c|c|c|c|}
\hline Family & Species & $\begin{array}{l}\text { Biogeographic } \\
\text { origin }\end{array}$ & $\begin{array}{l}\text { Life } \\
\text { form }\end{array}$ & $\begin{array}{c}\text { State park } \\
\text { Flor del } \\
\text { Bosque } \\
\text { Oak forest }\end{array}$ & $\begin{array}{l}\text { Eucalyptus } \\
\text { plantations }\end{array}$ & Grasslands & $\begin{array}{c}\text { Sierra } \\
\text { del } \\
\text { Tentzo }\end{array}$ \\
\hline \multirow{6}{*}{ Rubiaceae } & $\begin{array}{l}\text { Amelanchier denticulata (Kunth) K. } \\
\text { Koch }\end{array}$ & $\mathrm{N}$ & WS & 1 & 5 & ND & ND \\
\hline & $\begin{array}{l}\text { Crataegus mexicana Moc. et Sessé } \\
\text { ex DC. }\end{array}$ & $\mathrm{N}$ & WS & 13 & ND & ND & ND \\
\hline & $\begin{array}{l}\text { Bouvardia multiflora (Cav.) Schult. } \\
\text { et Schult. f. }\end{array}$ & $\mathrm{N}$ & WS & 21 & 17 & ND & ND \\
\hline & Bouvardia ternifolia (Cav.) Schltdl. & $\mathrm{N}$ & WS & 6 & 10 & ND & ND \\
\hline & Randia capitata DC. & $\mathrm{N}$ & WS & ND & ND & ND & 2 \\
\hline & $\begin{array}{l}\text { Randia echinocarpa Moc. and Sessé } \\
\text { ex DC. }\end{array}$ & $\mathrm{N}$ & WS & ND & ND & ND & 2 \\
\hline Sapindaceae & Dodonaea viscosa Jacq. & $\mathrm{N}$ & WS & 12 & 32 & ND & 40 \\
\hline Verbenaceae & $\begin{array}{l}\text { Lantana velutina M. Martens et } \\
\text { Galeotti }\end{array}$ & $\mathrm{N}$ & WS & 121 & 115 & ND & ND \\
\hline
\end{tabular}

was 630 individuals/ha; Eucalyptus were not included in this estimation since they were intentionally introduced in the park and are not part of the original flora. Nevertheless, within the forest relict (i.e., without considering Eucalyptus plantations and grasslands), the estimated density of trees increased to 1143 individuals/ha.

Oaks (Quercus spp.) were the most representative group of trees in the park (83.9\% of the total trees), and more than $99 \%$ of oaks were detected at the forest relict. Neither adult nor recruits of oaks were detected at the Eucalyptus plantations and just a few, isolated adult oaks were recorded at the grasslands (Table 1). The most abundant oak species within the forest relict were Quercus castanea and $Q$. laeta, with more than 300 individuals/ ha each. They were followed by $Q$. glabrescens and $Q$. laurina, with 105 and 86 individuals/ha, respectively. The other 5 oaks species we recorded had less than 30 individuals/ha (Table 1).

The total density of shrubby plants at the park was estimated in 1597 individuals/ha. The family Fabaceae was the best represented group, including the $35.7 \%$ of the total shrubs recorded in this site. However, the most abundant shrub species was Salvia polystachya (Lamiaceae), with an estimated density of 432 individuals/ha. It was followed by Mimosa aculeaticarpa, Eysenhardtia polystachya, Senecio salignus and Lantana velutina, all of which showed densities above 120 individuals/ha; all the remaining shrub species showed densities lower than 81 individuals/ ha (Table 1). Within the forest, the dominant shrub species in the understory was $S$. polystachya, while the shrub community at the Eucalyptus plantation was co-dominated by Calliandra grandiflora and Agave potatorum, both with more than 110 individuals/ha. In the grasslands, all shrub species showed densities lower than 15 individuals/ ha (Table 1).

Within the plantations, some individuals of $E$. camaldulensis were taller than $25 \mathrm{~m}$ and their trunk diameter at the breast height surpasses $30 \mathrm{~cm}$. These older trees are regularly arranged, spaced $6 \mathrm{~m}$ each other. This allows to estimate that the original sowing density at plantations was 278 individuals/ha. Nevertheless, smaller individuals (1-5 m tall) are spreading within plantations, which seem to be product of both sexual and vegetative reproduction of older trees. Therefore, by considering both older and younger trees, our estimations indicated that the current density of E. camaldulensis in the plantations is 312 individuals/ha (Table 1). We also found some small eucalypts trees in the interior of the forest relict, having an estimated density of 9 individuals/ha (Table 1).

On the slopes of Sierra of Tentzo we recorded 40 woody plant species, belonging to 16 families (Table 1). No exotic species were detected at this site. Up to $15 \%$ of these species were endemics to Mexico (Table 1), but none of them are protected by the Mexican Normativity of Environmental Protection (DOF, 2010). In this site, oaks were the most common trees $(68.3 \%$ of the total sampled individuals). However, just 6 oak species were recorded at this site, including $Q$. castanea, $Q$. glaucoides, $Q$. laeta, $Q$. laurina, $Q$. mexicana and $Q$. rugosa. The most abundant tree species was $Q$. laeta, with 216 individuals/ha followed 
Table 2. Bird species lists from the oak forest relict and the eucalyptus plantations of the state park Flor del Bosque and from the external site, Sierra del Tentzo. The table indicates the family, name and authority (following the Integrated Taxonomic Information System database of the Smithsonian Institution; http://www.itis.gov, consulted on May 14 $\left.4^{\text {th }} 2011\right)$, and biogeographic origin (N/PR= native/permanent-resident; $\mathrm{N} / \mathrm{Mi}=$ native/migratory; En= Endemic) of each species the different sites considered in this study. The body of the table indicates the number of times we recorded each species at the different habitat types of the park and at Sierra del Tentzo; ND= not detected

\begin{tabular}{|c|c|c|c|c|c|c|c|c|}
\hline \multirow[b]{3}{*}{ Family } & \multirow[b]{3}{*}{ Species } & \multirow[b]{3}{*}{$\begin{array}{l}\text { Biogeographic } \\
\text { origin }\end{array}$} & \multicolumn{3}{|c|}{ Summer 2010} & \multirow{2}{*}{\multicolumn{2}{|c|}{$\begin{array}{l}\text { Winter } 2011 \\
\text { State park Flor del } \\
\text { Bosque }\end{array}$}} & \multirow{3}{*}{$\begin{array}{l}\text { Sierra } \\
\quad \text { del } \\
\text { Tentzo }\end{array}$} \\
\hline & & & \multicolumn{2}{|c|}{$\begin{array}{c}\text { State park Flor del } \\
\text { Bosque }\end{array}$} & \multirow{2}{*}{$\begin{array}{c}\text { Sierra } \\
\text { del } \\
\text { Tentzo }\end{array}$} & & & \\
\hline & & & Oak forest & $\begin{array}{l}\text { Eucalyptus } \\
\text { plantations }\end{array}$ & & $\begin{array}{l}\text { Oak } \\
\text { forest }\end{array}$ & $\begin{array}{l}\text { Eucalyptus } \\
\text { plantations }\end{array}$ & \\
\hline Accipitridae & $\begin{array}{l}\text { Buteo swainsoni } \\
\text { (Bonaparte, 1838) }\end{array}$ & $\mathrm{N} / \mathrm{Mi}$ & ND & ND & ND & ND & 9 & ND \\
\hline Aegithalidae & $\begin{array}{l}\text { Psaltriparus minimus } \\
\text { (Townsend, 1837) }\end{array}$ & $\mathrm{N} / \mathrm{PR}$ & 8 & ND & 11 & 5 & 2 & 12 \\
\hline Cardinalidae & $\begin{array}{c}\text { Pheucticus } \\
\text { melanocephalus } \\
\text { (Swainson, 1827) }\end{array}$ & $\mathrm{N} / \mathrm{PR}$ & 2 & 2 & 2 & 3 & 2 & 1 \\
\hline Ciconiidae & $\begin{array}{c}\text { Cathartes aura } \\
\text { (Linnaeus, 1758) }\end{array}$ & $\mathrm{N} / \mathrm{PR}$ & 4 & ND & 3 & 4 & ND & 2 \\
\hline Columbidae & $\begin{array}{l}\text { Zenaida asiatica } \\
\text { (Linnaeus, 1758) }\end{array}$ & $\mathrm{N} / \mathrm{PR}$ & 2 & ND & 3 & 1 & 1 & 1 \\
\hline Corvidae & $\begin{array}{l}\text { Aphelocoma ultramarine } \\
\text { (Bonaparte, 1825) }\end{array}$ & En & 5 & 3 & ND & 6 & 1 & ND \\
\hline \multirow[t]{4}{*}{ Emberizidae } & $\begin{array}{c}\text { Aimophila mystacalis } \\
\text { (Hartlaub, 1852) }\end{array}$ & En & 4 & ND & 6 & 2 & ND & 2 \\
\hline & $\begin{array}{l}\text { Pipilo erythrophthalmus } \\
\text { (Linnaeus, 1758) }\end{array}$ & $\mathrm{N} / \mathrm{PR}$ & 10 & 4 & ND & 5 & ND & ND \\
\hline & $\begin{array}{c}\text { Pipilo fuscus (Swainson, } \\
1827 \text { ) }\end{array}$ & $\mathrm{N} / \mathrm{PR}$ & 4 & ND & 12 & ND & ND & 16 \\
\hline & $\begin{array}{l}\text { Spizella passerine } \\
\text { (Bechstein, 1798) }\end{array}$ & $\mathrm{N} / \mathrm{PR}$ & ND & 16 & 9 & 2 & 5 & 8 \\
\hline \multirow[t]{2}{*}{ Fringillidae } & $\begin{array}{c}\text { Carduelis psaltria (Say, } \\
1823 \text { ) }\end{array}$ & $\mathrm{N} / \mathrm{PR}$ & 5 & 4 & 4 & 3 & ND & 4 \\
\hline & $\begin{array}{l}\text { Carpodacus mexicanus } \\
\text { (Statius Muller, 1776) }\end{array}$ & $\mathrm{N} / \mathrm{PR}$ & 6 & 2 & ND & 2 & 3 & ND \\
\hline \multirow[t]{2}{*}{ Icteridae } & $\begin{array}{l}\text { Icterus parisorum } \\
\text { (Bonaparte, 1838) }\end{array}$ & $\mathrm{N} / \mathrm{Mi}$ & ND & ND & ND & ND & 8 & 2 \\
\hline & $\begin{array}{l}\text { Molothrus aeneus } \\
\text { (Wagler, 1829) }\end{array}$ & $\mathrm{N} / \mathrm{PR}$ & ND & 2 & ND & ND & ND & ND \\
\hline \multirow[t]{2}{*}{ Parulidae } & $\begin{array}{l}\text { Basileuterus rufifrons } \\
\text { (Swainson, 1838) }\end{array}$ & En & 3 & ND & 4 & 1 & ND & 2 \\
\hline & $\begin{array}{c}\text { Dendroica coronata } \\
\text { auduboni (J. K. } \\
\text { Townsend, 1837) }\end{array}$ & $\mathrm{N} / \mathrm{Mi}$ & ND & ND & ND & 2 & 11 & 1 \\
\hline \multirow[t]{3}{*}{ Picidae } & $\begin{array}{l}\text { Melanerpes aurifrons } \\
\text { (Wagler, 1829) }\end{array}$ & $\mathrm{N} / \mathrm{PR}$ & ND & ND & 2 & ND & ND & 1 \\
\hline & $\begin{array}{l}\text { Melanerpes formicivorus } \\
\quad \text { (Swainson, 1827) }\end{array}$ & $\mathrm{N} / \mathrm{PR}$ & 6 & ND & ND & 4 & ND & ND \\
\hline & $\begin{array}{l}\text { Picoides villosus } \\
\text { (Linnaeus, 1766) }\end{array}$ & $\mathrm{N} / \mathrm{PR}$ & 2 & 3 & 3 & 1 & 1 & 1 \\
\hline
\end{tabular}


Table 2. Continues

\begin{tabular}{|c|c|c|c|c|c|c|c|c|}
\hline \multirow[b]{3}{*}{ Family } & \multirow[b]{3}{*}{ Species } & \multirow[b]{3}{*}{$\begin{array}{l}\text { Biogeographic } \\
\text { origin }\end{array}$} & \multicolumn{3}{|c|}{ Summer 2010} & \multirow{2}{*}{\multicolumn{2}{|c|}{$\begin{array}{l}\text { Winter } 2011 \\
\text { park Flor del } \\
\text { Bosque }\end{array}$}} & \multirow{3}{*}{$\begin{array}{l}\text { Sierra } \\
\quad \text { del } \\
\text { Tentzo }\end{array}$} \\
\hline & & & \multicolumn{2}{|c|}{$\begin{array}{c}\text { State park Flor del } \\
\text { Bosque }\end{array}$} & \multirow{2}{*}{$\begin{array}{c}\text { Sierra } \\
\text { del } \\
\text { Tentzo }\end{array}$} & & & \\
\hline & & & Oak forest & $\begin{array}{l}\text { Eucalyptus } \\
\text { plantations }\end{array}$ & & $\begin{array}{c}\text { Oak } \\
\text { forest }\end{array}$ & $\begin{array}{l}\text { Eucalyptus } \\
\text { plantations }\end{array}$ & \\
\hline Thraupidae & $\begin{array}{c}\text { Piranga flava (Vieillot, } \\
\text { 1822) }\end{array}$ & $\mathrm{N} / \mathrm{PR}$ & ND & 4 & ND & ND & 1 & ND \\
\hline \multirow[t]{3}{*}{ Trochilidae } & $\begin{array}{l}\text { Amazilia beryllina } \\
\text { (Deppe, } 1830)\end{array}$ & En & 3 & ND & 2 & 2 & ND & 1 \\
\hline & $\begin{array}{l}\text { Calothorax Lucifer } \\
\text { (Swainson, 1827) }\end{array}$ & $\mathrm{N} / \mathrm{Mi}$ & ND & ND & ND & 2 & ND & ND \\
\hline & $\begin{array}{l}\text { Eugenes fulgens } \\
\text { (Swainson, 1827) }\end{array}$ & $\mathrm{N} / \mathrm{PR}$ & 1 & ND & ND & 1 & 1 & ND \\
\hline \multirow[t]{2}{*}{ Troglodytidae } & $\begin{array}{c}\text { Campylorhynchus gularis } \\
\text { (Sclater, 1861) }\end{array}$ & En & 1 & ND & 1 & 1 & ND & 2 \\
\hline & $\begin{array}{c}\text { Campylorhynchus } \\
\text { rufinucha (Lesson, 1838) }\end{array}$ & En & 1 & ND & 2 & 2 & ND & 2 \\
\hline Turdinae & $\begin{array}{l}\text { Turdus rufopalliatus } \\
\text { (Lafresnaye, 1840) }\end{array}$ & En & 3 & 1 & ND & 4 & 1 & ND \\
\hline \multirow[t]{3}{*}{ Tyrannidae } & $\begin{array}{c}\text { Camptostoma imberbe (P. } \\
\text { L. Sclater, 1857) }\end{array}$ & $\mathrm{N} / \mathrm{PR}$ & 2 & 5 & ND & 1 & 4 & ND \\
\hline & $\begin{array}{l}\text { Pyrocephalus rubinus } \\
\text { (Boddaert, 1783) }\end{array}$ & $\mathrm{N} / \mathrm{PR}$ & 2 & 2 & ND & ND & ND & ND \\
\hline & $\begin{array}{l}\text { Tyrannus melancholicus } \\
\text { (Vieillot, 1819) }\end{array}$ & $\mathrm{N} / \mathrm{PR}$ & 3 & 16 & ND & 2 & 2 & ND \\
\hline Vireonidae & $\begin{array}{c}\text { Vireo huttoni (Cassin, } \\
1851)\end{array}$ & $\mathrm{N} / \mathrm{PR}$ & 4 & ND & ND & 3 & ND & ND \\
\hline
\end{tabular}

by Juniperus flaccida var. flaccida, with 148 individuals/ ha, and $Q$. castanea and $Q$. laurina, both with more than 130 individuals/ha. All the other tree species had less than 70 individuals/ha (Table 1). Among the shrubby species, there was a clear dominance of the palm Brahea dulcis, with 438 individuals/ha followed by $M$. aculeaticarpa, represented by 168 individuals/ha. The densities of all the other shrub species at this site were lower than 40 individuals/ha (Table 1).

Only native species were considered for the rarefaction analyses. Taking into account both trees and shrubs, the oak forest relict showed significantly higher values of $S$ and $H^{\text {' }}$ than the other habitat types within the park. Conversely, the lowest values of these 2 community attributes were estimated in the grasslands, while Eucalyptus plantations obtained intermediate values (Figs. 2a, b). The same patterns were obtained for $S$ and $H^{\prime}$ 'when only trees were included in the analyses (Figs. 2c, d). For shrubs, the oak forest and the Eucalyptus plantations showed similar values of $S$ and $H$ ' and, in both cases, these values were significantly higher than those from grasslands (Figs. 2e, f). Neither $S$ nor $H^{\text {' }}$ differed between the park and Sierra del Tentzo when all woody species were considered altogether (Figs. 2a, b). The richness of tree species, whoever, was significantly higher within the park than at Sierra del Tentzo (Fig. 2c).

Diversity of birds. In the sampling conducted during the summer of 2010, we recorded 25 bird species within Flor del Bosque (Table 2). As expected for this season, all species were permanent-resident birds. Campylorhynchus rufinucha was the only species included in the Mexican Normativity of Environmental Protection in the category of endangered species (DOF, 2010). Six bird species detected within the oak forest relict were endemic to Mexico, but 2 of them were also recorded at the Eucalyptus plantation (Table 2). Pipilo erythrophthalmus was the most common bird species within the oak forest, with 10 records. At the Eucalyptus plantations, the most common species were Tyrannus melancholicus, with 16 records, and Spizella passerine, with 15 records (Table 2 ).

In Sierra del Tentzo, we recorded 14 bird species in summer (Table 2). With the exception of Melanerpes aurifrons, all bird species from this site were also present in Flor del Bosque park. Five species from Sierra del Tentzo were endemic to Mexico, including the endangered species 


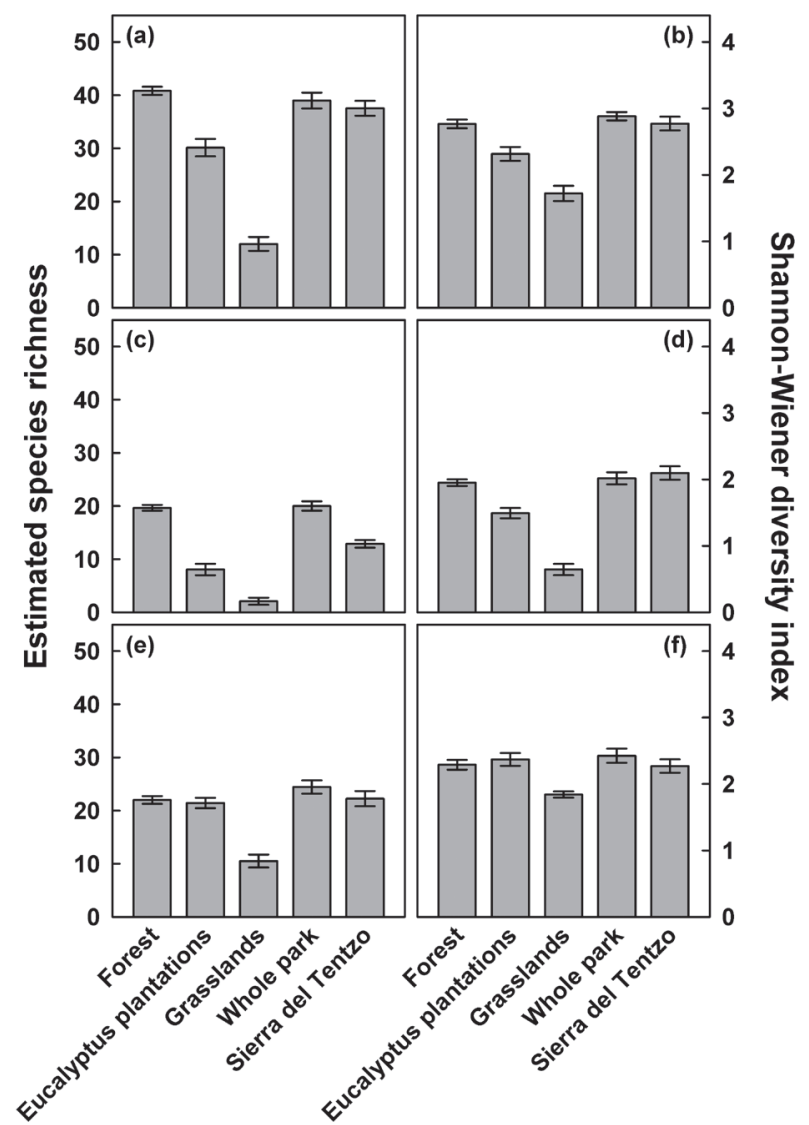

Figure 2. Values of species richness (left column) and the Shannon-Wiener diversity index (right column) estimated after 1000 rarefaction runs at a sampling size of 20 transects for woody plant species. These estimations were firstly performed by including all species recorded at the different sites (panels [a] and $[\mathrm{b}]$ ). Later, these estimations were separately conducted for trees (panels [c] and [d]) and shrubs (panels [e] and [f]). Bars are averages $\pm 95 \%$ C.I.; significant differences among sites were assumed if their $95 \%$ C.I. do not overlap.

C. rufinucha (DOF, 2010). At this site, Pipilo fuscus and Psaltriparus minimus were the most commonly recorded species during summer, with 12 and 11 records, respectively (Table 2).

Rarefaction analyses conducted with summer data indicated that the bird community within the oak forest of the park was significantly richer and more diverse than that at Eucalyptus plantations. Moreover, when compared with the external site, the park as a whole showed significantly higher numbers of bird species and higher values of diversity than Sierra del Tentzo (Figs. 3a, b).

In the winter of 2011, 4 migratory bird species were recorded in the park, together with another 22 permanentresident birds (Table 2). All migratory birds were recorded in the Eucalyptus plantations, but 2 of them were also detected

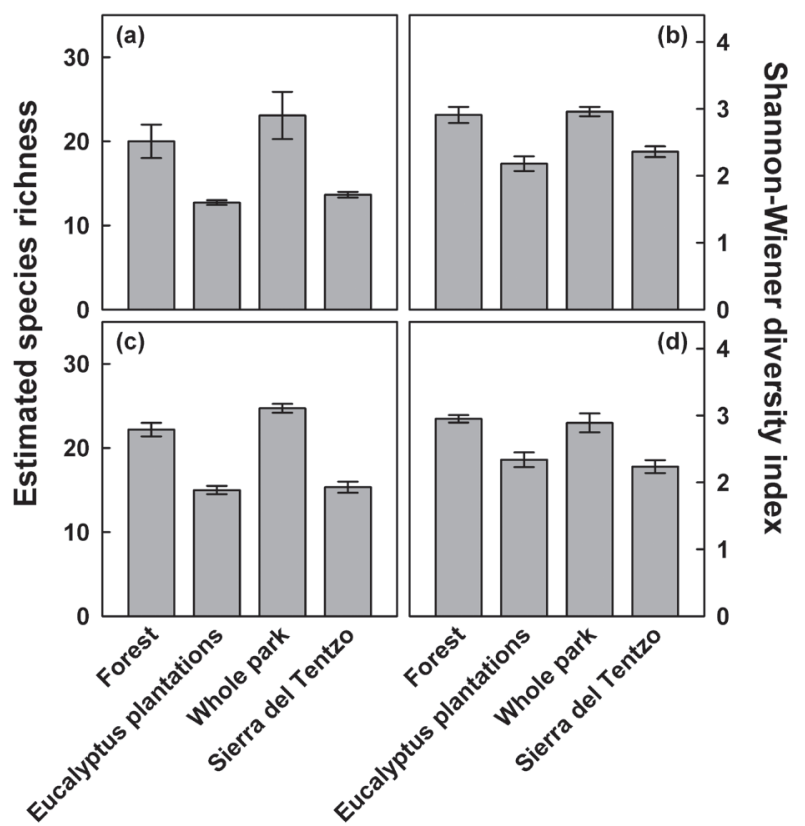

Figure 3. Values of species richness (left column) and the Shannon-Wiener diversity index (right column) estimated after 1000 rarefaction runs at a sampling size of 52 individuals for bird species. These estimations were performed separately for the samplings conducted at summer 2010 (panels [a] and [b]) and winter 2011 (panels [c] and [d]). Bars are averages $\pm 95 \%$ C.I.; significant differences among sites were assumed if their $95 \%$ C.I. do not overlap.

in the oak forest (Table 2). During this season, we detected 2 permanent-resident bird species included as endangered in the Mexican Normativity of Environmental Protection (C. mexicanus and C. rufinucha). Nevertheless, Buteo swainsoni, a migratory species that arrived to the Eucalyptus plantations of the park, is considered as subjected to special protection by the current normativity. The most commonly recorded species at the park in winter was the migratory bird Dendroica coronata auduboni, with 11 records at the Eucalyptus plantations and 2 at the oak forest (Table 2).

In Sierra del Tentzo, a total of 16 bird species were recorded during winter, but just 2 of them (Icterus parisorum and $D$. coronata auduboni) were migratory. Only $C$. rufinucha, which was also recorded in summer, was included in the Mexican Normativity of Environmental Protection (DOF, 2010). At this site, P. fuscus and P. minimus were the bird species with the higher number of records during winter (Table 2).

The rarefaction analyses we performed with winter data showed that both $S$ and $H^{\prime}$ followed the same pattern than in summer. Within the park, both community attributes 
were indicated to be higher in the oak forests than in the Eucalyptus plantations. In the winter season, the park was also richer and more diverse that the oak forest at Sierra del Tentzo (Figs. 3c, d).

\section{Discussion}

Our results allow us to suggest that the state park Flor del Bosque is effectively acting as a local reservoir of flora and fauna for the state of Puebla. Regarding the woody flora, this suggestion seems to be especially valid for trees because the small forest relic of the park contains more species than the larger and well-preserved forested area we used as external site of comparison. The strong emphasis we put on the tree species is because most of the area now occupied by the city of Puebla was originally covered by this type of oak-dominated forests (Rzedowski, 1965). This does not mean that shrubby species are less important, but most of these species colonize disturbed sites and correspond to the early stages of plant succession (Rzedowski and Calderón de Rzedowski, 1993), as occurred in the Eucalyptus plantation and grasslands of the park.

Besides oaks, which are the most conspicuous woody species at the park, it is important to note that this NPA is also preserving a highly charismatic tree species of Mexico. This is the case of $C$. lusitanica, subjected to special protection in the Mexican Normativity of Environmental Protection, and Pittocaulon praecox, one of the rarest tree species in the park, which belongs to a Mexican endemic genus of the family Asteraceae (Villaseñor et al., 1998). The scarce adult oaks we found in the grasslands are probably relic trees that were maintained at these sites by the former landowners to provide shade for the cattle that grazed in these areas (Badano et al., 2009).

The results also suggest that the introduction of plantations of exotic tree species may be threating the local flora. This is because the increasing population size we estimated within plantations of $E$. camaldulensis suggests that this exotic species has become naturalized within the park (sensu Richardson et al., 2011). Moreover, since some eucalyptus individuals were recorded within the forest relic, it is feasible to think that a biological invasion process has been triggered. Here, it is important to note that several species of the genus Eucalyptus have been reported to reduce germination and growth of other plant species via allelopathic effects or other detrimental biochemical interactions related to the release of organic compounds into the environment (Jaiyeob, 1998; Dadkhah and Asaadi, 2010). However, more studies are required in order to determine the current impact that eucalyptus trees have on both native species and local ecosystem processes.
Regarding the bird communities, the higher diversity recorded within the park, as compared to Sierra del Tentzo, suggests that this small NPA has a substantial conservation value for these organisms. Indeed, the diversity analysis conducted in summer suggests that the permanent-resident birds would use this NPA as refuge throughout the entire year, and also indicated that the oak forest relict would be more important than Eucalyptus plantations. This could be a consequence of the higher structural complexity of the former habitat type, which may provide safer sites for nesting and feeding than Eucalyptus plantations for permanent-resident birds highly sensitive to anthropogenic disturbances (Wilson et al., 1994; Stotz et al., 1996). On the other hand, although the winter sampling indicated more migratory birds using the park than Sierra del Tentzo, the number of migratory birds was higher at the Eucalyptus plantation than at any other site. This suggests that the migratory birds would prefer human-disturbed habitats, concurring with the result of other studies that have shown that several North American migratory birds prefer disturbed, semi-open habitats in their wintering home range because this decreases competition with permanent resident-birds (Hutto, 1989; Sherry and Holmes, 1996; Petit et al., 2003).

All these results indicate that the park should be considered a conservation priority by the local government authorities. Moreover, although we only focused on woody plants and birds, it is also feasible that other groups of organisms are being protected within this small NPA. For instance, in the herbaceous layer, we incidentally observed the presence of the insectivorous plant Pinguicula moranensis var. neovolcanica (Lentibulariaceae), a rare endemic species that is only present across the TransMexican Volcanic Belt (Zamudio, 1999). Therefore, despite its small surface area, and despite the strong loses of natural habitats (i.e., oak forests) that affected the area in the past, the relevance of this park as NPA is still high. Further, apart from preserving the local diversity, this park is highly effective to communicate the results generated by scientific research projects to the general population. In the last 6 years, the park has received 691820 visitors, many of them children from elementary schools, which are instructed on the biodiversity contained at this site and several other environmental issues (information provided by the administration of the park). Thus, the park is also performing an important educational activity by generating environmental awareness among society.

As a concluding remark, this study clearly illustrate that the creation of small NPAs may result in a highly effective strategy for preserving local biodiversity, even when they are surrounded by highly disturbed anthropogenic landscapes. Therefore, we suggest that these 
types of scientific initiatives should be promoted by the administrations of other states of Mexico since this would allow the determination of whether or not their NPAs are preserving the local biodiversity and the development of adequate management programs for these sites.

\section{Acknowledgments}

We thank the financial support provided by Fondo Mixto de Fomento a la Investigación Científica y Tecnológica CONACYT-Gobierno del Estado de Puebla, number 108571. We also thank the logistic support provided by the staff of the park Flor del Bosque and Secretaría del Medio Ambiente y Recursos Naturales of State of Puebla, and Nayeli Prieto for revising the spelling, grammar and style of the English version of the manuscript.

\section{Literature cited}

Badano, E. I., D. Pérez and C. H. Vergara. 2009. Love of nurse plants is not enough for restoring oak forests in a seasonally dry tropical environment. Restoration Ecology 17:571-576

Badano, E. I., O. R. Samour-Nieva and J. Flores. 2011. Emulating nurse plants to restore oak forests. Ecological Engineering 37:1244-1248

Chalif, E. L. and R. T. Peterson. 1999. A field guide to Mexican birds: Mexico, Guatemala, Belize, El Salvador. Houghton Mifflin Harcourt, Boston, Massachusetts. 320 p.

Colwell, R. K. 2009. EstimateS: Statistical estimation of species richness and shared species from samples. User's Guide and application published at: http://purl.oclc.org/estimates; last access: 03.XII.2011.

Espinosa-Organista, D., S. Ocegueda-Cruz, C. AguilarZúñiga, O. Flores-Villela and J. Llorente-Bousquetss. 2008. El conocimiento biogeográfico de las especies y su regionalización natural. In Capital natural de México, Vol. I, Conocimiento actual de la biodiversidad, J. Sarukhán, J. Soberón, G. Halffter and J. Llorente-Bousquetss (eds.). Comisión Nacional para el Conocimiento y Uso de la Biodiversidad, México, D. F. p. 33-65.

Dadkhah, A. and A. M. Asaadi. 2010. Allelopathic effects of Eucalyptus camaldulensis on seed gennination and growth seedlings of Acroptilon repens, Plantago lanceolata and Portulaca oleracea. Research Journal of Biological Sciences 5:430-434.

DOF (Diario Oficial de la Federación). 2010. Norma Oficial Mexicana NOM-059-SEMARNAT-2010, Protección ambiental - Especies nativas de México de flora y fauna silvestres - Categorías de riesgo y especificaciones para su inclusión, exclusión o cambio - Lista de especies en riesgo, Secretaría de Medio Ambiente y Recursos Naturales, México, D. F. 30 de diciembre de 2010.
García, E. 1988. Modificaciones al sistema de clasificación climática de Köppen para adaptarlo a las condiciones de la República Mexicana. Universidad Nacional Autónoma de México, México, D. F. p. 246.

Gotelli, N. J. and R. K. Colwell. 2001. Quantifying biodiversity: Procedures and pitfalls in the measurement and comparison of species richness. Ecology Letters 4:379-391.

Gotelli, N. J. and J. L. Entsminger. 2011. EcoSim: Null models software for ecology. User's Guide and application published at: http://garyentsminger.com/ecosim/index.htm; last access: 03.XII.2011.

Gutiérrez-Herrera, L., M. J. Cuervo-Morales and E. O. Ortiz. 2003. Regiones naturales y planeación para el Estado de Puebla. Análisis Económico UAM-Azcapotzalco 18:257296.

Howell, S. N. G. and S. Webb. 1995. A guide to the birds of Mexico and Northern Central America. Oxford University Press, New York. 1010 p.

Hutto, R. L. 1989. The effect of habitat alteration on migratory land birds in a west Mexican tropical deciduous forest: A conservation perspective. Conservation Biology 3:138-148.

INEGI (Instituto Nacional de Estadística, Geografía e Informática). 1987. Síntesis Geográfica, Nomenclátor y Anexo Cartográfico del Estado de Puebla. Aguascalientes. $56 \mathrm{p}$.

Jaiyeob, I. A. 1998. Changes in soil properties related to conversion of savannah woodland into pine and eucalyptus plantations, Northern Nigeria. Land Degradation and Development 9:207-215.

Krebs, C. J. 1999. Ecological methodology, 2nd ed. Benjamin Cummings, Menlo Park, California. 624 p.

Ocegueda, S. and J. Llorente-Bousquets. 2008. Catálogo taxonómico de especies de México. In Capital natural de México, Vol. I, Conocimiento actual de la biodiversidad, J. Sarukhán, J. Soberón, G. Halffter and J. Llorente-Bousquetss (eds.). Comisión Nacional para el Conocimiento y Uso de la Biodiversidad, México, D. F. Anexo 2.

Petit, L. J. and D. R. Petit. 2003. Evaluating the importance of human-modified lands for neotropical bird conservation. Conservation Biology 17:687-694.

Rzedowski, J. 1965. Relaciones geográficas y posibles orígenes de la flora de México. Boletín de la Sociedad Botánica de México 29:121-177.

Rzedowski, J. and G. Calderón de Rzedowski. 1993. Datos sobre la dinámica de la flora fanerogámica del Valle de México, con énfasis en especies nativas raras, en peligro de extinción o aparentemente extintas. Acta Botanica Mexicana 25:81108.

Rzedowski, J. 2006. La vegetación de México. Comisión Nacional para el Conocimiento y Uso de la Biodiversidad, México, D. F. 400 p.

Richardson, D. M., P. Pyšek and J. T. Carlton. 2011. A compendium 
of essential concepts and terminology in invasion ecology. In Fifty years of invasion ecology: the legacy of Charles Elton, D. M. Richardson (ed.). Wiley-Blackwell, Oxford. p. 409-420.

Sherry, T. W. and R. T. Holmes. 1996. Winter habitat quality, population limitation, and conservation of neotropicalneartic migrant birds. Ecology 77:36-48.

Stotz, D. F., J. W. Fitzpatrick, T. A. Parker and D. K. Moskovits. 1996. Neotropical birds: ecology and conservation. University of Chicago Press, Chicago. 478 p.

Vargas-Márquez, F., S. Escobar and R. del Ángel. 2000. Áreas naturales protegidas de México con decretos federales. Instituto Nacional de Ecología y Secretaria de Medio Ambiente, Recursos Naturales y Pesca, México, D. F. 830 p.
Vargas-Márquez, F., R. de la Maza-Elvira and R. M. del PontLalli. 2001. Áreas naturales protegidas de México con decretos estatales. Instituto Nacional de Ecología y Comisión Nacional de Áreas Naturales Protegidas, México, D. F. 620 p. Villaseñor, J. L., G. Ibarra and D. Ocaña. 1998. Strategies for the conservation of Asteraceae in Mexico. Conservation Biology 12:1066-1075.

Wilson, M. F., T. L. de Santo, C. Sabag and J. J. Armesto. 1994. Avian communities of fragmented south-temperate rainforest in Chile. Conservation Biology 8:508-520.

Zamudio, S. 1999. Notas sobre la identidad de Pinguicula moranensis H.B.K., con la descripción de una variedad nueva. Acta Botanica Mexicana 49:23-34. 